\title{
A new high-resolution habitat distribution map for Austria, Liechtenstein, southern Germany, South Tyrol and Switzerland
}

\author{
Michael Kuttner, Franz Essl, Johannes Peterseil, Stefan Dullinger, Wolfgang Rabitsch, Stefan Schindler, Karl \\ Hülber, Andreas Gattringer \& Dietmar Moser
}

Keywords: biosphere reserves; Central Europe; Eastern Alps; EUNIS habitats; habitat distribution; land cover; mapping; national parks; nature conservation areas

\section{Abstract}

There is a growing need for fine-scale data on habitat distribution for large areas to comprehensively detect changes in biodiversity patterns, ecosystem service provision and sustainable landscape development against global change. We present a map of 19 habitat classes at a resolution of 25 m for Austria, Germany (Baden-Wurttemberg, Bavaria), Liechtenstein, Italy (South Tyrol) and Switzerland. Fine-scale data from various sources in the public domain (e.g. habitat mapping campaigns, Open Street Map, CORINE land cover 2006 (CLC2006), Joint Research Centre forest mapping, GIO-Land high resolution layers) were harmonized and supplemented by remote mapping and modelling techniques. Spatio-thematic accuracy checks with independent data sources have been conducted and the habitat classes further compared to the CLC2006 classification scheme. As a first map application we provide habitat class-specific proportions for national parks and biosphere reserves located within the mapping area in relation to their surroundings and further discuss additional fields of applications. The map will be freely available for non-commercial scientific use.

\section{Introduction}

The most widely used dataset to derive land-cover patterns in Europe is CORINE land cover 2006 (CLC2006) (EEA 2007). Its wide coverage, largely homogeneous methodology, the data quality and a resolution of $100 \mathrm{~m}$ are attractive for many applications. However, its limited thematic accuracy, particularly the poor differentiation of (semi)natural ecosystems, and the coarse minimum mapping area of 25 ha, make it insufficient for many ecological questions, which focus on small remnants of particularly interesting habitats like dry grasslands or wetlands. In contrast, datasets of high spatial and thematic resolution, such as national inventories of ecosystems of high conservation value (e.g. floodplains, dry grasslands, mires; Holzner 1986; Steiner 1992), biotope mapping campaigns (e.g. LfU 2012; LUBW 2014), Natura 2000 mapping (European Commission 2006), forest inventory databases (Bauerhansl et al. 2008) or agricultural databases (e.g. the land parcel information system LPI), are mainly gathered at a (sub)national level in Central Europe and therefore have a restricted spatial range. Although high-resolution layers on a larger spatial scale have become recently available for specific habitat and land cover classes, such as forests (Joint Research Centre; JRC (Kempeneers et al. 2011) and GIO land monitoring service (Langanke 2013)), built-up areas and transport networks (Open Street Map; OSM), or grasslands and waterbodies (GIO land (Langanke 2013)), substantial methodological differences (e. g. different classification schemes) have hampered their integration at a supra-national level.

Here we present the first high-resolution Central European Habitat map (CEH) (freely available at: $\mathrm{ftp}: / / 131.130 .33 .15)$ that is focusing on semi-natural habitat classes of high conservation value. It covers approx. $240000 \mathrm{~km}^{2}$ across Austria, Liechtenstein, southern Germany (Bavaria, Baden-Wurttemberg), Italy (South Tyrol) and Switzerland. Standardized procedures of resampling, harmonizing and merging of available high-resolution mapping and remote sensing data ensure a ready-to-use dataset consisting of 19 habitat classes.

We also provide a comparison with the most commonly used land-cover dataset of CLC2006.

\section{Methods}

\section{Data preparation and map generation}

Datasets from various sources (Table 1) were projected to the ETRS 1989 LAEA spatial reference system. Vector data were converted into native ESRI GRID raster format with a spatial resolution of $25 \mathrm{~m}$ $\times 25 \mathrm{~m}$. To be consistent with other European datasets, the grid origin was defined by CORINE. Original data were reclassified according to our habitat specifications and separate grid layers for each class were generated. As a general purpose we applied fine-scale data wherever available to improve the spatial and thematic accuracy of CORINE, but used CLC2006 data to fill the remaining gaps.

\section{Roads, railways, watercourses and lakes}

Data on Roads, Railways and Watercourses were extracted from OSM line vector datasets. For the sake of consistency with the grid cell size $(25 \mathrm{~m})$ only motorways, main railway lines and large rivers (i.e. wider than $30 \mathrm{~m}$ ) were considered. Data on Lakes originating from the ECRINS database and provided in vector format were converted to raster format. 


\section{Built-up areas}

We merged several built-up land-cover classes from OSM (village green; residential; industrial; commercial) and CLC2006 (Continuous urban fabric (1.1.1); Discontinuous urban fabric (1.1.2); Industrial and commercial units (1.2.1); Dump sites (1.3.2); Construction sites (1.3.3)) and additionally integrated high-resolution data on imperviousness from GIO-Land to capture even single farmsteads and hamlets.

\section{Forests}

Obviously misclassified forest pixels from JRC source data, located in the nival and upper alpine altitudinal belt, were deleted using exclusion masks derived from CLC2006 layers Glaciers and perpetual snow (3.3.5) and Bare rock (3.3.2).

\section{Shrub lands}

For this ecosystem class we extracted habitat-specific data from mapping campaigns (Bavaria, BadenWurttemberg) and a WebGIS service (Geobrowser) for South Tyrol. For Austria we extracted data from national biotope mapping (2656 - F2 Arctic, alpine and subalpine scrub, 2784 - F3 Temperate and mediterraneanmontane scrub, 2889 - F4 Temperate shrub heathland, 3355 - F8 Thermo-Atlantic xerophytic scrub). For Switzerland and Liechtenstein we used the CLC2006 class Transitional woodland scrub (3.2.4).

\section{Extensive grasslands and alpine grasslands}

These habitat classes comprise mesic low-impact pastures and meadows below the tree line as well as alpine grasslands. For Bavaria and Baden-Wurttemberg we compiled data from the latest available biotope and FFH mapping campaigns, particularly the Bayrisches Ökoflächenkataster and Biotopverbund BadenWürttemberg (LfU 2012; LUBW 2014). For Switzerland we used data from Résean écologique national (Berthoud et al. 2004). For Liechtenstein extensively used grasslands were identified by a supervised image classification which was conducted using ArcGIS 10.1 and later corrected by cross-checking with data on lownutrient grassland habitats from the geodata portal of Liechtenstein. South Tyrolean data originated from a remote sensing campaign which has been conducted by the Italian Department of Agriculture (AGEA) in 2008 and were accessed via Geobrowser. Finally, Austrian data were again taken from IACS by integrating a selection of EUNIS Level III classes which indicate low-impact management (summarized under EUNIS Level II class 2182 - E2 Mesic grasslands). We additionally used EUNIS class 2302 - E4 Alpine and subalpine grasslands, derived from Dirnböck \& Peterseil 2014, for completion. Remaining gaps were filled by CLC2006 class Natural grassland (3.2.1). To differentiate extensively managed lowland from alpine grasslands across all countries we modelled the actual forest lines. Forest data from JRC and GIO-Land were cleaned from misclassified pixels using CLC2006 exclusion layers and restricted to areas with a minimum mean temperature of $6.4^{\circ} \mathrm{C}$ during the growth period and a minimum length of the growth period of 90 days, beyond which climate conditions are unsuitable for tree growth (Körner 2012). Altitude was derived from the latest pan-European digital elevation data (EU-DEM) with a common spatial resolution of $25 \mathrm{~m}$ (EEA 2013). By applying focal statistics and kriging interpolation techniques we obtained a final dataset on the actual distribution of the upper tree limit across the Alps.

\section{Dry grasslands}

This ecosystem class includes various types of dry and semi-dry meadows and pastoral lands. We used several data sources: biotope mapping campaigns (Bavaria, Baden-Wurttemberg, Liechtenstein), Bundesamt für Umwelt (BAFU, Switzerland) and an updated version of the Austrian inventory of dry grasslands (Holzner 1986 - updated 2013). For South Tyrol we again used data provided by the WEBGIS source Geobrowser. Gaps in the South Tyrolean dataset were filled by a niche modelling approach. We defined the thresholds for the potential occurrence of dry grasslands with respect to annual precipitation $(<832 \mathrm{~mm})$, slope $\left(>10^{\circ}\right.$ and $\left.<48^{\circ}\right)$, aspect (south $155^{\circ}-205^{\circ}$ ) and elevation $(<1680 \mathrm{~m})$ as the mean plus the twofold standard deviation of already outlined dry grassland sites across South Tyrol. Those reference values were then compared with the Swiss dataset in order to check if dimensions of the ecological space of dry grasslands appear reasonable. Topographic parameters and precipitation were derived from EU-DEM and from WorldClim (Hijmans et al. 2005; spatial resolution: 30 arc s; i. e. approx. $1 \mathrm{~km} \times 1 \mathrm{~km}$ ), respectively. Additionally, dry grassland patches complying with these rules had to be previously identified as Extensive grasslands.

\section{Mires and wet grasslands}

For the compilation of this class, which includes wet grasslands, sedge stands, reed beds, fens and mires, we compiled data from the same sources as for Dry grasslands. For Austria, in addition, data from the Austrian mire inventory (Steiner 1992) were used, together with several classes from Dirnböck \& Peterseil 2014 (5257 - X04 Raised bog complexes; 1724 - D4 Base-rich fens and calcareous spring mires; 1589 - D2 Valley mires, poor fens and transition mires, 1515 -D1 Raised and blanket bogs, 1404 - C3 Littoral zone of inland water bodies, 1797 - D5 Sedge and reed beds without free standing water, 2238 - E3 Seasonally wet and wet grasslands) who compiled additional data sources from national habitat monitoring efforts.

\section{Vineyards and orchards}

Similar to Built up areas, OSM data were used to enhance the spatial coverage for vineyards and orchards which were based on CLC2006 data. For South Tyrol we integrated information on vineyards and orchards, identified by the AGEA remote sensing campaign 
Table 1 - Summary of the major data sources used to compile the CEH. Geographic code: $A T=$ Austria; BA=Bavaria; BW=Baden-Wurttemberg; $\mathrm{CH}=$ Switzerland; $L I=$ Liechtenstein; $S T=$ South Tyrol

\begin{tabular}{|c|c|c|}
\hline Habitat Class & Data source & Geographic coverage \\
\hline $\begin{array}{l}\text { Coniferous forest [CFO] } \\
\text { Broad leaved forest [BLFO] }\end{array}$ & JRC-forest mapping campaign & whole area \\
\hline Shrub lands [SHRUB] & CLC2006; Geobrowser; Biotope mapping data & $\begin{array}{l}\mathrm{CLC} 2006=\mathrm{CH}, \mathrm{LI} \text { (partly in AT, ST, BA, BW for completion); Geo- } \\
\text { browser = ST; Biotope mapping data = AT, BA, BW }\end{array}$ \\
\hline Arable land [ARAB] & CLC2006; IACS data & $\mathrm{CLC} 2006=\mathrm{CH}, \mathrm{LI}, \mathrm{ST}, \mathrm{BA}, \mathrm{BW} ; \mathrm{IACS}=\mathrm{AT}$ \\
\hline Intensively used grasslands [IGR] & CLC2006; GIO-LAND & CL2006 = whole area; GIO-LAND = whole area \\
\hline Vineyards [VIN] & CLC2006; OSM; Geobrowser; IACS data & $\begin{array}{l}\mathrm{CLC} 2006=\mathrm{BA}, \mathrm{BW}, \mathrm{CH} ; \mathrm{OSM}=\text { whole area; Geobrowser }=\mathrm{ST} ; \\
\mathrm{IACS}=\mathrm{AT}\end{array}$ \\
\hline Orchards [ORC] & CLC2006; OSM; Geobrowser & $\mathrm{CLC} 2006=\mathrm{BA}, \mathrm{BW}, \mathrm{CH}, \mathrm{AT} ; \mathrm{OSM}=$ whole area; Geobrowser $=\mathrm{ST}$ \\
\hline Lakes [LAKE] & EEA data (ECRINS database) & whole area \\
\hline $\begin{array}{l}\text { Major rivers [RIV] } \\
\text { Major railways [RAIL] } \\
\text { Major roads [ROAD] }\end{array}$ & OSM & whole area \\
\hline Built up areas [BUA] & CLC2006; OSM; GIO-LAND & whole area \\
\hline $\begin{array}{l}\text { Extensive grasslands [EXTGR] } \\
\text { Alpine grasslands [ALPGR] }\end{array}$ & $\begin{array}{l}\text { Biotope mapping data; REN; Supervised Image } \\
\text { Classification; Geobrowser }\end{array}$ & $\begin{array}{l}\text { Biotope mapping data }=\mathrm{BA} \text {, BW, } \mathrm{AT} \text {; } \mathrm{REN}=\mathrm{CH} ; \mathrm{SIC}=\mathrm{LI} \text {; Geo- } \\
\text { browser }=\mathrm{ST}\end{array}$ \\
\hline Mires and wet grasslands [WET] & $\begin{array}{l}\text { Biotope mapping data; Geobrowser; Austrian } \\
\text { mire inventory }\end{array}$ & Biotope mapping data $=\mathrm{BA}, \mathrm{BW}, \mathrm{CH}, \mathrm{LI} ; \mathrm{Geobrowser}=\mathrm{ST} ; \mathrm{Ami}=\mathrm{AT}$ \\
\hline Dry grasslands [DRY] & $\begin{array}{l}\text { Biotope mapping data; Geobrowser; Austrian } \\
\text { Inventory of dry grasslands (updated 2013) }\end{array}$ & Biotope mapping data $=\mathrm{BA}, \mathrm{BW}, \mathrm{CH}, \mathrm{LI}$; Geobrowser $=\mathrm{ST}$; $\mathrm{Adg}=\mathrm{AT}$ \\
\hline Gravel banks [GRAVEL] & Visual classification campaign & whole area \\
\hline $\begin{array}{l}\text { Rocks [ROCK] } \\
\text { Glaciers [GLAC] }\end{array}$ & CLC2006 & whole area \\
\hline
\end{tabular}

\begin{tabular}{|c|c|}
\hline \multicolumn{2}{|c|}{ Source of freely available data, their original spatial resolution and date of origin } \\
\hline $\begin{array}{l}\text { JRC forest mapping } \\
\text { Resolution: } 25 \mathrm{~m} / 2006\end{array}$ & http://forest.jrc.ec.europa.eu/activities/forest-mapping/forest-cover-map-2006/ \\
\hline $\begin{array}{l}\text { ECRINS database } \\
\text { Vector data*/2011 }\end{array}$ & http://projects.eionet.europa.eu/ecrins/library/hydrography/v1/ecrlakmdb \\
\hline $\begin{array}{l}\text { OSM } \\
\text { Vector data } /^{* *}\end{array}$ & http://download.geofabrik.de/europe.html \\
\hline $\begin{array}{l}\text { CLC2006 } \\
\text { Resolution: } 100 \text { m/2006 }\end{array}$ & http://www.eea.europa.eu/data-and-maps/data/corine-land-cover-2006-raster \\
\hline $\begin{array}{l}\text { GIO-LAND } \\
\text { Resolution: } 10 \mathrm{~m} / 2012\end{array}$ & http://land.copernicus.eu/pan-european/high-resolution-layers/view/ \\
\hline $\begin{array}{l}\text { Biotope mapping BA } \\
\text { Vector Data / } 2012\end{array}$ & http://www.lfu.bayern.de/gdi/dls/biotopkartierung.xml \\
\hline $\begin{array}{l}\text { Biotope mapping BW } \\
\text { Vector data/ } 2012\end{array}$ & http://www.lubw.baden-wuerttemberg.de/servlet/is/61722/ \\
\hline $\begin{array}{l}\text { Biotope mapping } \mathrm{CH} \\
\text { Vector data/2007-2013 }\end{array}$ & http://www.bafu.admin.ch/gis/02911/07403/index.htmlelang=de \\
\hline $\begin{array}{l}\text { WebGIS Liechtenstein } \\
\text { Vector data/NA }\end{array}$ & http://geodaten.llv.li/geoshop/naturlandschaft.html/ \\
\hline $\begin{array}{l}\text { Geobrowser South Tyrol } \\
\text { Vector data / 2008- }\end{array}$ & http://gis2.provinz.bz.it/geobrowser/?project=geobrowser_pro\&view=geobrowser_pro_atlas-b\&locale=de \\
\hline
\end{tabular}

* Not all acquired vector datasets share a specific resolution or minimum mapping unit

** OSM-datasets are continuously updated by the user community (date of download: April 2013)

and accessed by using the Geobrowser. Vineyards in Austria were updated by data from the IACS database (reference year 2012) of the Austrian Federal Ministry of Agriculture, Forestry, Environment and Water Management.

\section{Arable land}

To define Arable land we used IACS data for Austria, supplemented by the CLC2006 classes of Nonirrigated arable land (2.1.1) and Complex cultivation patterns (2.4.2) in the other countries.
Intensively used grasslands

We used the CLC2006 classes Pastures (2.3.1) and Land principally occupied by agriculture, with significant areas of natural vegetation (2.4.3) which had not yet been classified as another class (e.g. Extensive grassland, Mires and wet grasslands, etc.) in any of the fine-scale datasets. Additionally we used the Permanent grasslands layer from GIO-Land for areas that were already covered by the Arable land class. 
Table 2 - Nineteen habitat classes of the CEH and their corresponding CLC2006 and EUNIS habitats. Habitat class abbreviations correspond to Table 1.

\begin{tabular}{|c|c|c|c|c|}
\hline $\begin{array}{l}\text { Habitat } \\
\text { Class }\end{array}$ & $\begin{array}{l}\text { Corresponding EUNIS } \\
\text { Level } 1 / 2 / 3 \text { habitat }\end{array}$ & Remarks - EUNIS & $\begin{array}{l}\text { Corresponding CLC2006 } \\
\text { habitat (Level 3/4) }\end{array}$ & Remarks - CLC \\
\hline CFO & G3 & $\begin{array}{l}\text { Transition to class G4 (mixed forests) } \\
\text { occurs }\end{array}$ & 3.1 .2 & Transitions to 3.1.3 (Mixed forests) may occur \\
\hline BLFO & G1 & $\begin{array}{l}\text { Transition to class G4 (mixed forests) } \\
\text { may occur }\end{array}$ & 3.1 .1 & $\begin{array}{l}\text { Minor transitions to } 3.1 .3 \text { (Mixed forests) } \\
\text { may occur }\end{array}$ \\
\hline SHRUB & F2/F3/F4/F9/E5.2 & $\begin{array}{l}\text { E5.2 indicates shrub dominated wood- } \\
\text { land fringes }\end{array}$ & 3.2.2.2/3.2.4 & 3.2.2.2 indicates Pinus mugo stands \\
\hline ARAB & $11 /(12)$ & $\begin{array}{l}\text { Some parts of Arable land may also be } \\
\text { covered by class } 12\end{array}$ & $2.1 .1 / 2.4 .2$ & - \\
\hline IGR & E2.1 /E2.2/E2.6 & - & 2.3.1/2.4.3.2 & - \\
\hline VIN & FB.4 & - & 2.2 .1 & - \\
\hline ORC & FB. 3 & - & 2.2 .2 & -- \\
\hline LAKE & $\mathrm{Cl}$ & - & 5.1 .1 .1 & - \\
\hline RIV & $\mathrm{C} 2$ & - & 5.1 .2 .1 & - \\
\hline RAIL & $J 4.3$ & - & 1.2.2.2 & - \\
\hline ROAD & $\mathrm{J} 4.2$ & - & 1.2.2.1 & - \\
\hline BUA & $\mathrm{J1} / \mathrm{J} 2$ & $\begin{array}{l}\text { Coverage of class } \mathrm{J} 2 \text { is limited by the } \\
\text { minimum area corresponding } \mathrm{J} 2 \text { - } \\
\text { elements are comprising }\end{array}$ & $1.1 .1 / 1.1 .2 / 1.2 .1$ & - \\
\hline EXTGR & E2.1/E2.2/E2.7 & $\begin{array}{l}\text { Classes are partly overlapping with } \\
\text { IGR, but include areas at the extensive } \\
\text { end of the land use gradient }\end{array}$ & 3.2 .1 & - \\
\hline ALPGR & E2.3/E4 & $\begin{array}{l}\text { Some low-lying parts of class E2.3 may } \\
\text { fall into EXTGR }\end{array}$ & 3.2 .1 & - \\
\hline WET & D/E3.4/E3.5 & - & $4.1 .1 / 4.1 .2$ & - \\
\hline DRY & $\mathrm{E} 1 / \mathrm{H} 2.5 / \mathrm{H} 2.6$ & $\begin{array}{l}\text { Semi-open thermophilous sites are } \\
\text { covered by classes } \mathrm{H} 2.5 / 6\end{array}$ & 3.2.1 & $\begin{array}{l}\text { Dry grasslands s.str. are not distinguished in } \\
\text { CLC, thus they are covered by class 3.2.1 }\end{array}$ \\
\hline GRAVEL & C3.6/C3.7 & - & 3.3.1.3 & - \\
\hline ROCK & $\mathrm{H} 2 / \mathrm{H} 3 / \mathrm{H} 5$ & - & 3.3 .2 & - \\
\hline GLAC & $\mathrm{H} 4$ & - & 3.3 .5 & - \\
\hline
\end{tabular}

EUNIS-levels are indicated by letter only (=Level 1); letter+number (=Level 2); letter+point-separated number (= Level 3). The CLC2006 classification scheme follows pointseparated number codes, the number of digits corresponding to the bierarchical level (e.g. 3-digit code $=$ Level 3 )

\section{Gravel banks}

The Gravel banks class was established by an onscreen visual interpretation based on Google Earth satellite imagery. Gravel banks along river systems across the entire study region with an approximate width $>25 \mathrm{~m}$ were digitized as vector polygons and then converted to raster format.

\section{Glaciers, rocks}

The habitat classes Glaciers and Rocks are based on the CLC2006 classes of Glaciers and perpetual snow (3.3.5) and Bare rock (3.3.2), respectively.

For setting up the final map we mosaicked the thematic layers by following the general rule that classes of high nature conservation value, which are often restricted to rather small areas, must not be overlain by more widespread classes like Arable land. In detail, the order for mosaicking the single class layers from top to bottom is: GRAVEL, GLAC, DRY, WET, EXTGR / ALPGR, SHRUB, ROCK, BUA, ROAD, RAIL, RIV, LAKE, ORC, VIN, IGR, ARAB, CFO / BLFO. This leads to a refinement of the coarse CLC2006 boundaries. For map harmonization and edge clearance purposes we finally applied minor boundary cleaning and majority filtering techniques.
Habitat classification

The CEH habitat classes are tied to the European classification systems of CORINE and EUNIS. Class specific assignments and additional remarks are listed in Table 2.

\section{Data accuracy}

To assess the degree of spatio-thematic precision between several datasets used for map generation, which is particularly important for remote-sensingbased datasets, we calculated a series of Kappa statistics using the Kappa statistics add-on tool in ArcGIS 10.1 by comparing the JRC forest layers (BLFO and $\mathrm{CFO}$ ) and the layer on Intensive used grasslands (IGR) with reference datasets from the IACS database not used for map creation. The forest evaluation data are spatially based on Austrian map ÖK 50 forest margins and thematically originate from GSE Forest Monitoring, while data on intensive grasslands were derived by filtering corresponding EUNIS classes. For the calculation of Kappa statistics we resampled IACS grassland data first to correspond with the final resolution of the CEH (i.e. $25 \mathrm{~m}$ ). We applied the same procedure with forest data after integrating the class mixed forest of the evaluation data into the class coniferous forest to comply with the $\mathrm{CEH}$ mapping scheme. For testing 


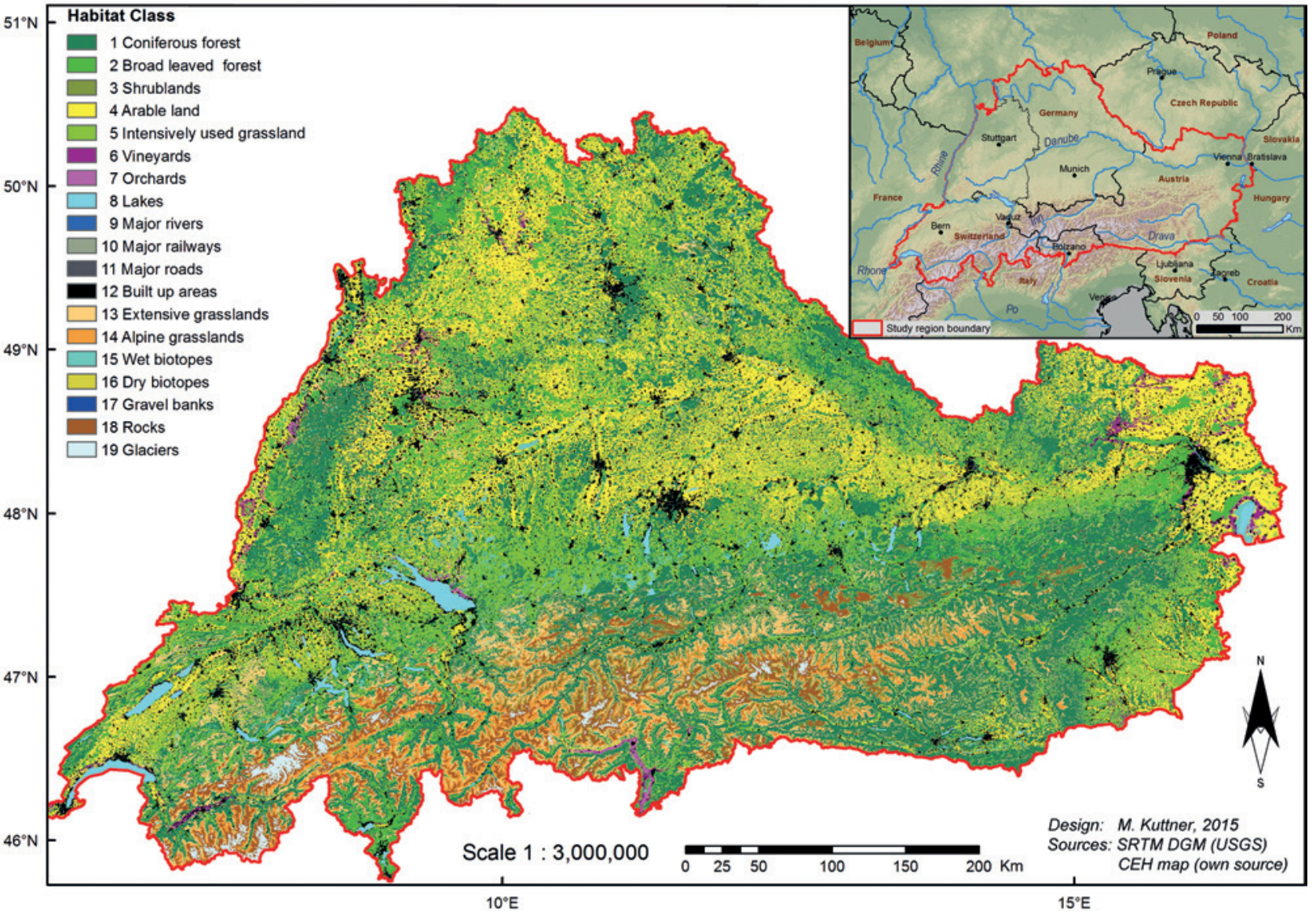

Figure 1 - The CEH (covering Austria, Baden-Wurttemberg, Bavaria, Liechtenstein, South Tyrol, Switzerland) represents 19 babitat classes

each dataset we randomly selected 250000 data points across Austria.

In addition we calculated Kappa statistics on a larger spatial scale by applying GMES Urban Atlas datasets for all available (peri-)urban areas within our mapping region. The area covered by these data corresponds to approx. $17 \%$ of the CEH. Urban Atlas classes with artificial areas of various densities were pooled to comply with CEH habitat class Built up areas, while Fast transit roads, Railways and Water could be easily related to corresponding $\mathrm{CEH}$ habitat classes. In order to gain a thematically comparable class that could be related to Agricultural, Semi-natural and wetland areas, we pooled the CEH classes Arable land, Intensive used grasslands, Vineyards, Orchards, Extensive grasslands and Mires and wet grasslands. We also pooled the CEH classes Coniferous forest and Broad leaved forest to comply with Forest as defined in the Urban Atlas. Again we selected a set of 250000 random points for computing Kappa statistics.

As independent reference data for South Tyrol and Switzerland are lacking, we extracted nationwide shares in major land-use/land-cover classes that could be related to our classification scheme from federal statistical databases. In the case of South Tyrol, forest classification also included (sub-)alpine dwarf pine stands, which have been classified as SHRUB within the CEH. The fuzzy distinction between those classes is indicated by the dot-dashed line in Table 5 . Similarly, the South Tyrolean proportion of Arable land should be treated as land used for intensive agriculture and therefore CEH class IGR must be also considered when comparing area proportions of this class as indicated by dashed lines in Table 5 .

\section{Mapping $\mathrm{CEH}$ class proportions of important} protected areas

As a first application of the $\mathrm{CEH}$ we calculated proportional shares of habitat classes for all national parks (NPs) and biosphere reserves (BRs) and their environs within the $\mathrm{CEH}$ region. To do so, we calculated minimum bounding geometries of each conservation area in ArcGIS 10.1. To allow for a comparison of reserve areas with their surroundings, we extended the bounding envelopes to include at least 1.5 times the conservation area and calculated the proportional shares of habitat classes also for the surrounding areas.

\section{Results}

The CEH consists of more than 383 million grid cells, covering an area of approximately $240000 \mathrm{~km}^{2}$, and consists of 19 habitat classes (Figure 1). The four most abundant habitat classes are Coniferous forests (28.8\%), Arable land (21.4\%), Intensively used grassland $(11.6 \%)$ and Broad leaved forests (9.6\%), which jointly 
cover approx. $71 \%$ of the study region. Proportional shares of all habitat classes for individual countries and federal states are given in Table 3.

The proportional shares of habitat classes differ markedly across the study region depending on altitude, geomorphology, land-cover proportions, landcover diversity, and land-use intensity as exemplified for selected landscapes in Figure 2.

Table 2 shows a crosslink between the habitat classification of the $\mathrm{CEH}$ and higher hierarchical levels of the most widely used European classification schemes, i. e. the EU Nature Information System (EUNIS) and CORINE (CLC2006). Clearly characterized CLC2006 classes, such as urban areas, arable lands or rock outcrops, are well represented by corresponding CEH classes, while complex CLC2006 categories, such as Complex cultivation patterns (2.4.2) or Transitional woodland-shrub (3.2.4), were split up and are represented by various CEH classes (Figure 3). The class Natural grasslands (3.2.1) (Figure 3 (b)) in particular was subdivided into EXTGR and ALPGR and the mixed class of Moors and heathland (3.2.2) was split up into classes CFO, SHRUB and EXTGR. Moreover, Complex cultivation patterns (2.4.2) as well as Land principally occupied by agriculture (4.1.2) (Figure 3 (c)) were divided into an agricultural matrix mainly consisting of ARAB, IGR, EXTR and BUA.

\section{Map validation}

A verification of the modelled forest limit was conducted by comparison with an available dataset on Swiss tree lines commissioned by the AGROSCOPE Institute (Szerencsits 2012). The mean deviation of our dataset from the Swiss treeline data equals at $128.5 \mathrm{~m}$, which corresponds well with the findings of Szerencsits (2012) who calculated mean deviations between forest lines and tree lines for major climatic regions of Switzerland between $81 \mathrm{~m}$ and $213 \mathrm{~m}$.

The results of the Kappa statistics revealed an observed agreement rate among GIO-LAND Intensive used grassland and IACS grassland data of $90.7 \%$ and a corresponding Kappa coefficient of $45.6 \%$. In case of the compared forest datasets, the observed agreement rate was $86.3 \%$ and the Kappa coefficient $75.5 \%$. Evaluation statistics of classes extracted from Urban Atlas data resulted in an overall observed agreement rate of $87.8 \%$ and a Kappa coefficient of $79.7 \%$.

The comparison between land cover derived from federal area statistic databases and proportional shares of CEH habitat classes is summarized in Table 5. Forests, arable land, grasslands and urban areas correspond well.

Habitat distribution within major conservation areas and their environs

To provide a first application of $\mathrm{CEH}$, we calculated the proportion of the habitat classes within NPs and BRs and their environs (Table 6). We found substantial differences in habitat proportions between protected
Table 3 - Habitat class composition across the study region and for Austria $(A T)$, Switzerland (CH), Liechtenstein (LI), South Tyrol (ST), Bavaria (BAV), Baden-Wurttemberg (BW).

\begin{tabular}{|l|r|r|r|r|r|r|r|}
\hline $\begin{array}{l}\text { Habitat } \\
\text { Class }\end{array}$ & $\begin{array}{l}\text { Mean overall } \\
\text { share (\%) }\end{array}$ & \% AT & \% BAV & \% BW & \% LI & \% CH & \% ST \\
\hline CFO & 28.8 & 35.1 & 27.3 & 23.1 & 34.7 & 22.5 & 33.3 \\
\hline BLFO & 9.6 & 9.7 & 8.1 & 14.5 & 4.9 & 9.2 & 3.1 \\
\hline SHRUB & 2.4 & 4.8 & 0.7 & 0.6 & 1 & 1.3 & 5.4 \\
\hline ARAB & 21.4 & 16.7 & 32.3 & 27.1 & 9.4 & 10.7 & 1.4 \\
\hline IGR & 11.6 & 7.3 & 17.1 & 12.5 & 7.7 & 11.2 & 6.7 \\
\hline VIN & 0.6 & 1 & 0.1 & 0.9 & 0.03 & 0.3 & 1 \\
\hline ORC & 0.2 & 0.02 & 0.03 & 0.5 & & 0.1 & 2.9 \\
\hline LAKE & 1.2 & 0.6 & 0.8 & 1 & & 2.2 & 0.2 \\
\hline RIV & 0.4 & 0.4 & 0.4 & 0.4 & 0.7 & 0.4 & 0.2 \\
\hline RAIL & 0.3 & 0.3 & 0.3 & 0.4 & 0.2 & 0.4 & 0.1 \\
\hline ROAD & 0.5 & 0.5 & 0.5 & 0.5 & 0.5 & 0.5 & 0.3 \\
\hline BUA & 6.8 & 5.2 & 7.8 & 9.8 & 11.9 & 6.9 & 1.4 \\
\hline EXTGR & 7.7 & 10.3 & 3 & 5.2 & 21.8 & 10.7 & 17.3 \\
\hline ALPGR & 3.3 & 3.6 & 0.1 & & 4.9 & 9.1 & 12.2 \\
\hline WET & 1 & 0.5 & 1.1 & 2.2 & 1.7 & 0.8 & 0.2 \\
\hline DRY & 0.6 & 0.4 & 0.3 & 1.3 & 0.7 & 0.8 & 1.1 \\
\hline GRAVEL & 0.04 & 0.04 & 0.02 & & 0.00 & 0.1 & 0.04 \\
\hline ROCK & 3 & 3 & 0.2 & & 0.1 & 8.9 & 11.1 \\
\hline GLAC & 0.7 & 0.7 & & & & 2.9 & 1.6 \\
\hline $\begin{array}{l}\text { Total Shares } \\
\text { (km }{ }^{2} \text { ) }\end{array}$ & 239005 & 83855 & 70553 & 35752 & 160 & 41285 & 7400 \\
\hline
\end{tabular}

areas and their environs. In particular, there often is a higher proportion of habitat classes of high nature conservation value, such as extensive grasslands, forests, dry and wetlands, in protected areas. Conversely, the proportions of heavily modified habitats, such as arable land, intensive grassland or built up areas, are higher outside nature reserves in most cases.

\section{Discussion}

Advances over previous ecosystem distribution maps

The CEH combines high spatial resolution with a thematic resolution that is suitable for an advanced and standardized representation of Central European habitats, allowing for analyses beyond that are supported by previous trans-national or national sources. For instance, the widely used European CLC2006 has a minimum mapping unit of 25 ha and a thematic resolution of 44 land-cover classes for the whole of Europe (EEA 2007). However, about 20\% are complex land-cover classes containing fundamentally different habitats (e.g. mixed arable land). This is a great obstacle for many ecological studies that depend on clearly delineated and fine-scale land-cover data (Schmit et al. 2006). In contrast, the CEH avoids mixed classification and aims at a spatially and thematically explicit distinction of individual habitats. For instance, we differentiate areas of intensively managed grassland from arable lands, whereas CLC2006 partly merges these classes into Land principally occupied by agriculture (4.1.2) or Complex cultivation patterns (2.4.2), together 

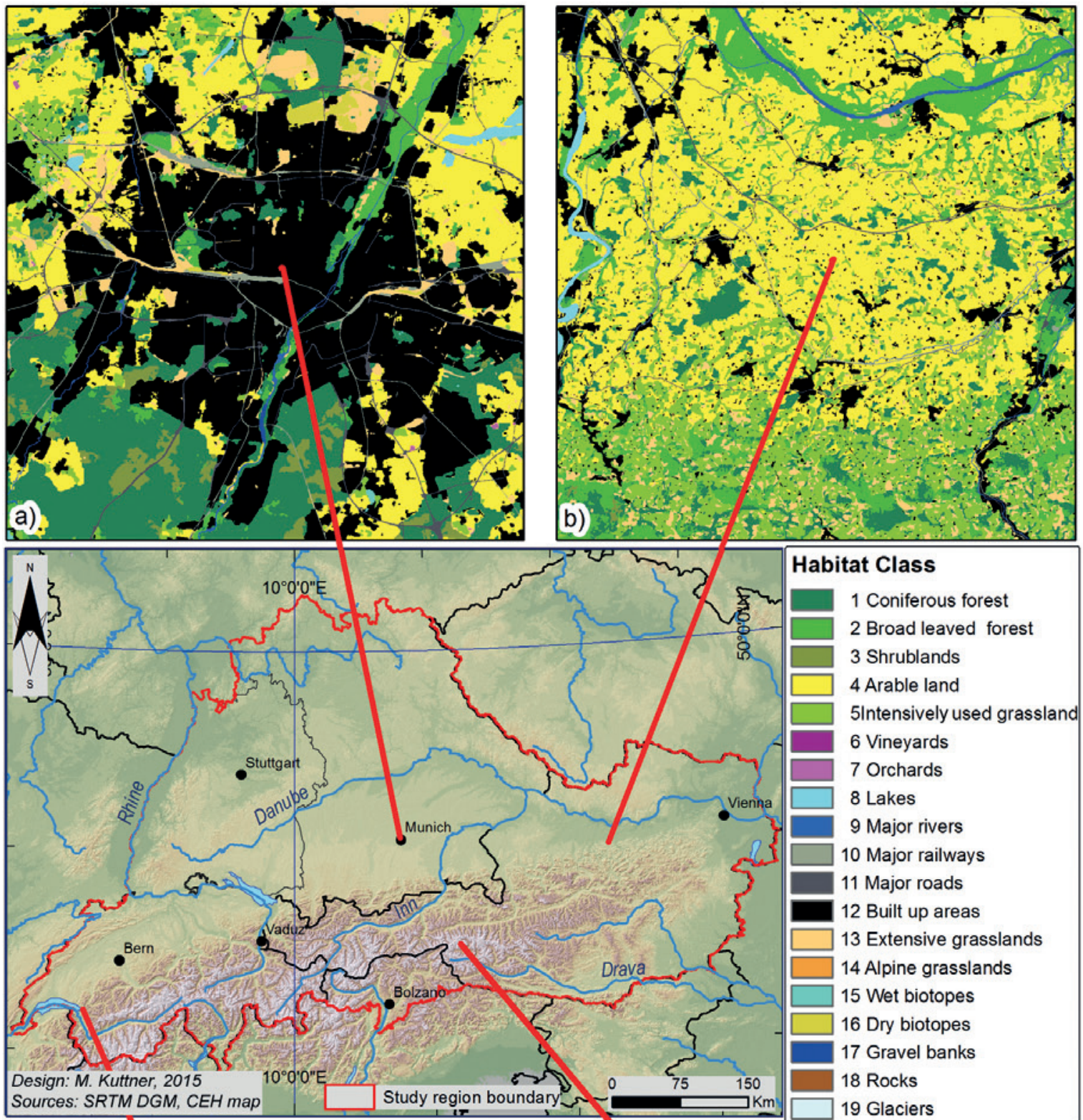

Habitat Class
1 Coniferous forest

2 Broad leaved forest

3 Shrublands

4 Arable land

5Intensively used grassland 6 Vineyards

7 Orchards

8 Lakes

9 Major rivers

10 Major railways

11 Major roads

12 Built up areas

13 Extensive grasslands

14 Alpine grasslands

15 Wet biotopes

16 Dry biotopes

17 Gravel banks

18 Rocks

19 Glaciers
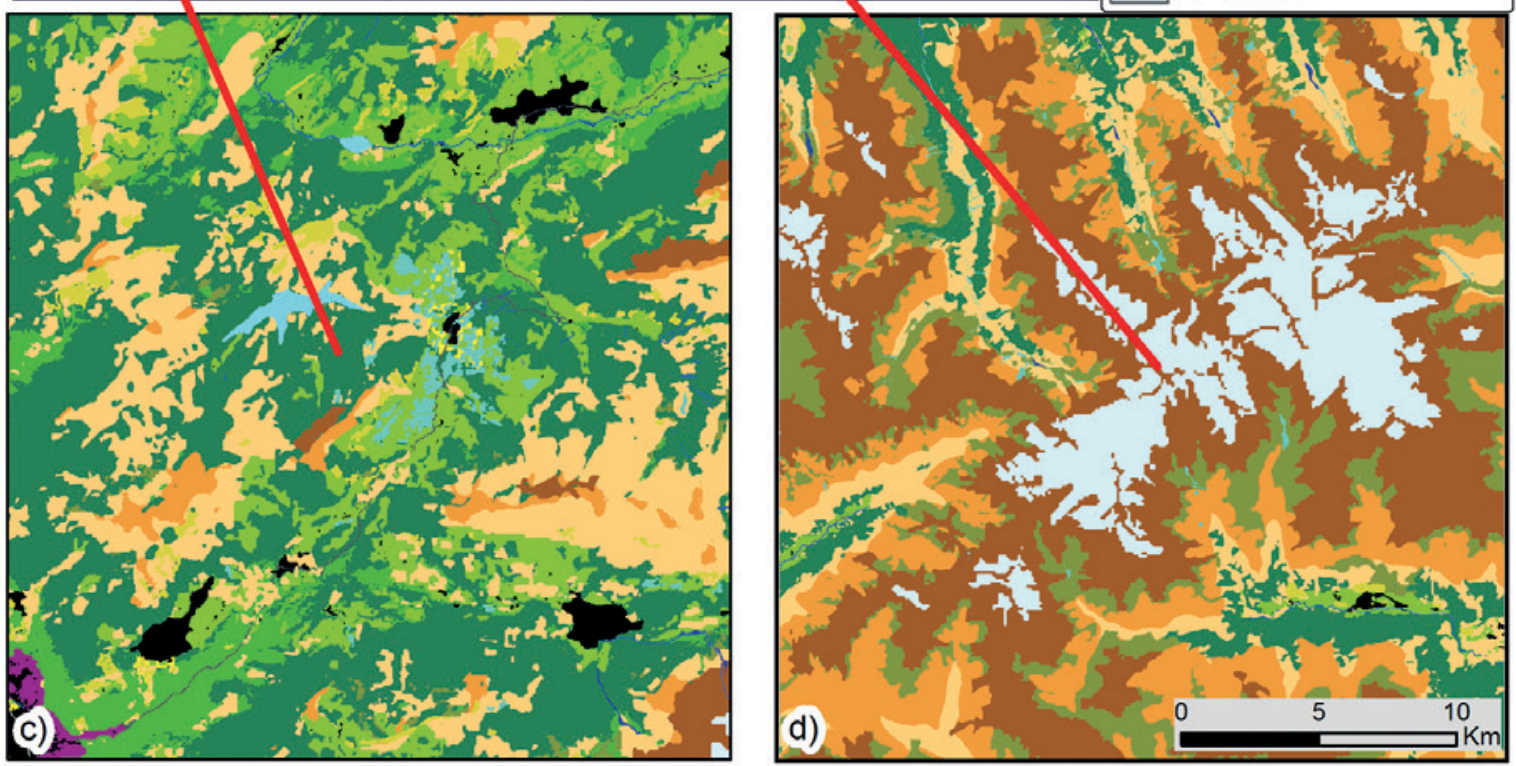

Figure 2 - Habitat classes of the CEH for sample landscapes: (a) a (peri)urban landscape (Munich, Germany); (b) an intensively used agricultural landscape (south-east of Linz. Austria); (c) an extensively used agricultural landscape (east of Lake Geneva, Switzerland); and (d) a high-altitude landscape with low land-use intensity in the Alps (Mount Großvenediger in the Hohe Tauern, Austria) 

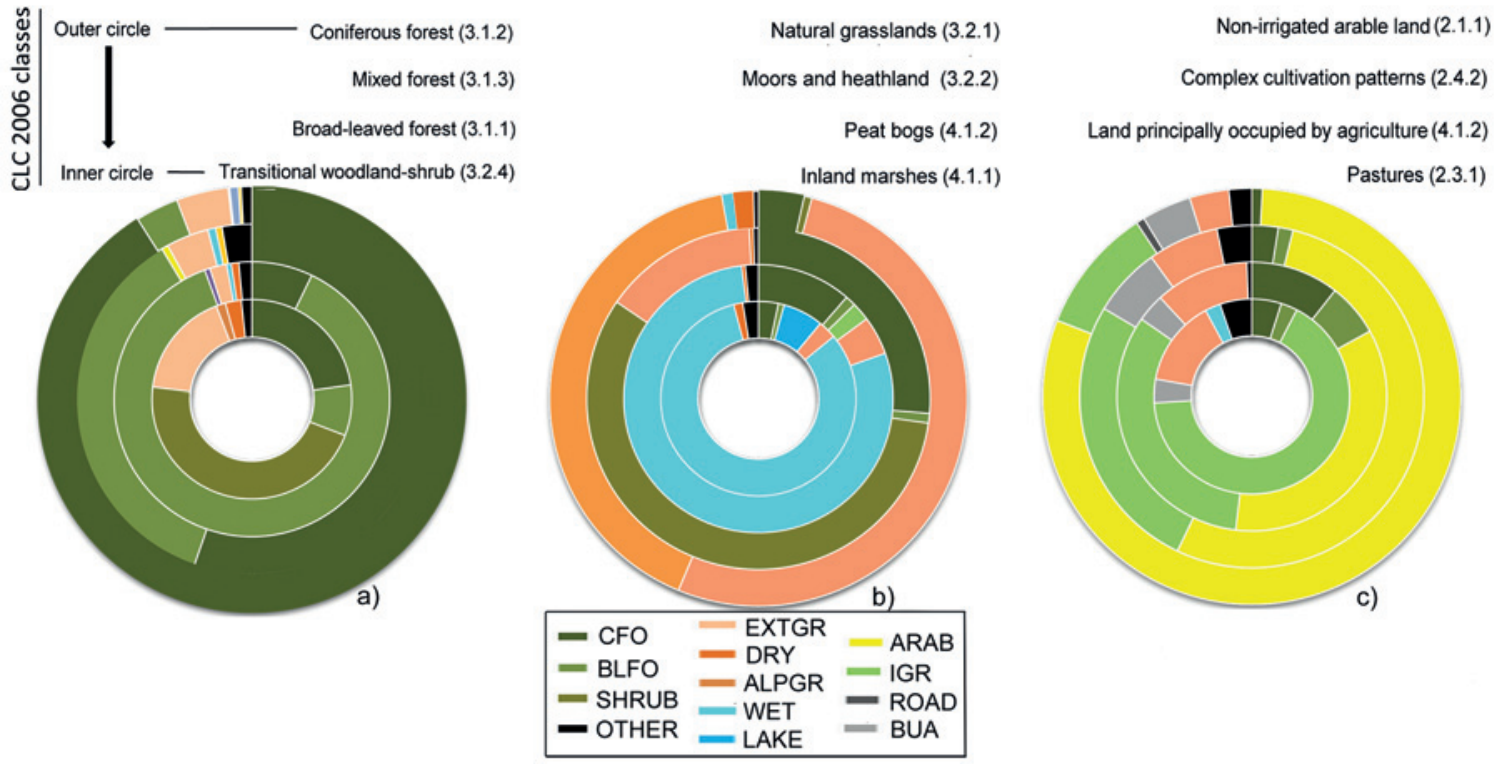

Figure 3 - CEH proportions compared to the most widely distributed CLC2006 classes, sectioned by (a) forest and shrub land classes, (b) grasslands and heath classes and (c) agriculturally dominated classes across the study region. Each circle represents one CLC2006 class.

with other minor land-use classes (cf. Figure 3). Further, we differentiate various types of (semi-)natural grasslands, such as Extensive grasslands, Alpine grasslands, Dry grasslands and Wet grasslands, which are of particular high value for nature conservation and serve as a reference point to analyse changes in habitat area and connectivity for rare and/or endangered species on large spatial scales (e.g. Hooftman \& Bullock 2012). In sum, the $\mathrm{CEH}$ substantially advances existing data sources on ecosystem distribution for the study region.

\section{Map validation}

We used Kappa statistics to test if transnational data sources, derived from remote sensing campaigns represent certain habitat classes adequately in terms of spatial and thematic accuracy. We found that this condition was met with some variability between different classes, documented by a range of Kappa coefficients from $45 \%$ for a subset of the Intensively used grassland habitat class (indicating a moderate strength of agreement according to Landis \& Koch 1977) to $75 \%$ for the forest classes, which corresponds to substantial strength of agreement. Good results were also achieved by the statistical validation using Urban Atlas Data (observed agreement rate: 87.8\%; Kappa coefficient: $79.7 \%$ ), see Table 4.

Those results should be interpreted in the context of observed agreement rates, which turned out even higher $(>90 \%)$ in cases of grasslands, even though Kappa coefficients only indicated moderate strength. The likely main reason for these somewhat divergent results is a high prevalence of negative cases (approx. $88 \%$ of NoData points) in our grassland data, as already explained by Kundel \& Polansky (2003). Vice versa, agreement rates and Kappa coefficients for Urban Atlas Data are rather close to each other because of almost full coverage of the respective point dataset within the test areas, which in turn means only few negative cases.

Spatial and thematic accuracy and their limitations

We aimed at using only current data sources (2006 or younger) for creating the $\mathrm{CEH}$ to account for rapid changes in landscape structure and ecosystem distribution in Central Europe (Falcucci et al. 2007). However, we occasionally had to resort to older datasets (e.g. Steiner 1992) to fill gaps in the distribution of high nature value habitat classes. We are aware that this approach might bias the maps towards greater spatial extension and lower fragmentation of habitat classes on high conservation value, particularly for the classes Mires and wet grasslands and Dry grasslands, because these ecosystems have continuously declined in recent decades (Klötzli \& Grootjans 2001; Cremene et al. 2005).

Table 4 - Confusion matrix obtained from Kappa statistic evaluation between Urban Atlas and CEH-map classes. AGRI $=[A R A B, I G R, V I N$, ORC $] ; \quad F O R E S T=[C F O, \quad B L F O] ; \quad A R T I F I C I A L=[B U A] ; \quad$ WATER $=[L A K E, \quad R I V] ;$ RAIL $=[R A I L] ; R O A D=[R O A D]$

\begin{tabular}{|c|c|c|c|c|c|c|}
\hline & AGRI & FOREST & ARTIFICIAL & WATER & RAIL & ROAD \\
\hline AGRI & 99789 & 6746 & 2820 & 550 & 147 & 62 \\
\hline FOREST & 4874 & 66178 & 699 & 565 & 27 & 51 \\
\hline ARTIFICIAL & 4008 & 1491 & 19253 & 161 & 124 & 41 \\
\hline WATER & 368 & 248 & 90 & 1200 & 5 & 1 \\
\hline RAIL & 341 & 121 & 282 & 20 & 362 & 11 \\
\hline ROAD & 454 & 201 & 288 & 10 & 11 & 403 \\
\hline \multirow[t]{2}{*}{ Counts } & 109834 & 74985 & 23432 & 2506 & 676 & 569 \\
\hline & \multicolumn{2}{|c|}{$\begin{array}{l}\text { Observed Agree- } \\
\text { ment: } 87.88 \%\end{array}$} & \multicolumn{2}{|c|}{$\begin{array}{l}\text { Chance Agreement: } \\
40.1 \%\end{array}$} & \multicolumn{2}{|c|}{$\begin{array}{l}\text { Kappa Coefficient: } \\
79.76 \%\end{array}$} \\
\hline
\end{tabular}


Table 5 - Area statistics (\%) of major land cover classes, derived from federal statistical databases within the mapping region, compared to CEH-class-specific shares (CEH-[country name]). Dotted line: indicating a fursy distinction between the classes; dashed lines: intenivly used arable land.

\begin{tabular}{|c|c|c|c|c|c|c|c|c|c|c|c|c|}
\hline $\begin{array}{l}\text { Habitat } \\
\text { class }\end{array}$ & AT $\%$ & CEH-AT\% & $\mathrm{CH} \%$ & CEH-CH \% & BW \% & CEH-BW \% & BA $\%$ & CEH-BA \% & ST \% & CEH-ST \% & 니 \% & CEH-LI \% \\
\hline CFO & 44.2 & 44.8 & 32.8 & 31.7 & 38 & 37.6 & 35.1 & 35.4 & 46.7 & 36.3 & 41 & 39.6 \\
\hline BLFO & & & & & & & & & & & & \\
\hline SHRUB & & & 2.1 & 1.3 & & & & & & 5.4 & & \\
\hline ARAB & 16.2 & 16.7 & 9.9 & 10.7 & 26.6 & 27.1 & 29.6 & 32.2 & \multirow{2}{*}{8.4} & 1.4 & 8.8 & 9.4 \\
\hline IGR & 6.7 & 7.3 & \multirow{2}{*}{24.8} & \multirow{2}{*}{21.9} & \multirow{2}{*}{17.6} & \multirow{2}{*}{17.7} & \multirow{2}{*}{19.5} & \multirow{2}{*}{20.1} & & 6.7 & \multirow{2}{*}{25.3} & \multirow{2}{*}{29.5} \\
\hline EXTGR & 8.7 & 10.3 & & & & & & & 17.5 & 17.3 & & \\
\hline VIN & 0.6 & 0.9 & 3.7 & 0.3 & 0.8 & 0.9 & & & \multirow{2}{*}{4} & \multirow{2}{*}{3.9} & & \\
\hline ORC & 0.1 & 0.01 & & & & & & & & & & \\
\hline BUA & 3.6 & 5.1 & 5.1 & 6.9 & 8.5 & 9.8 & 6.7 & 7.8 & 1.6 & 1.4 & 10 & 11.9 \\
\hline WET & & & & & & & & & 0.2 & 0.2 & & \\
\hline ROCK & & & 8.7 & 8.9 & & & & & 8 & 11.1 & & \\
\hline GLAC & & & 2.8 & 2.9 & & & & & 1.6 & 1.6 & & \\
\hline
\end{tabular}

\begin{tabular}{|l|l|l|}
\hline Country & Source & Links \\
\hline \multirow{2}{*}{ AT } & Statistik Austria & http://www.statistik.at/web_de/statistiken/land_und_forstwirtschaft/index.html \\
\cline { 2 - 3 } & Waldinventur 2007/2009 & http://bfw.ac.at/030/pdf/1818_pi24.pdf \\
\hline \multirow{2}{*}{ CH } & Bundesamt für Statistik & http://www.bfs.admin.ch/bfs/portal/de/index/themen/02/03/blank/data/01.html \\
\hline \multirow{2}{*}{ D } & Statistisches Landesamt Baden-Württemberg & http://www.statistik-bw.de/BevoelkGebiet/Landesdaten/geb_Flaechennutzung.asp \\
\cline { 2 - 3 } & Bayrisches Landesamt für Statistik & https://www.statistik.bayern.de/statistik/landwirtschaft/ \\
\hline \multirow{2}{*}{ IT } & Abtlg. Natur, Landschaft und Raumentwicklung & \multirow{2}{*}{ http://www.provincia.bz.it/natur-raum/themen/landeskartografie-realnutzungskarte.asp } \\
\cline { 2 - 3 } & Flächenstatistik der Realnutzungskarte & http://www.Ilv.li/files/au/pdf-Ilv-au-agrarbericht_2009.pdf \\
\hline \multirow{2}{*}{ LI } & Agrarbericht 2009 &
\end{tabular}

Furthermore, variation in data quality, spatial resolution and coverage between data sources might have caused differences in map quality across geographic regions (countries and federal states). For example, gaps in datasets of Dry grasslands in South Tyrol were filled by modelling approaches which potentially introduce errors. However, such effects on model quality should be low, because i) only very small parts of the $\mathrm{CEH}$ were complemented by modelling and ii) we carefully checked the additionally delineated cells by visual comparison with orthophoto imagery. Nevertheless, it is still possible that a few of the designated patches of Dry grasslands are irrigated and, thus, should be classified as extensive grasslands.

\section{Applicability and outlook}

A first application of the $\mathrm{CEH}$ has already been presented by calculating habitat distribution inside and outside the NPs and BRs covered by the map. However, those proportions must be considered case by case, as the location of the investigated conservation areas ranges from rather intensively used low-altitude landscapes to marginally utilized high-alpine space.

Other fields of application of habitat maps are manifold and relevant in various scientific disciplines, such as ecology, geography or nature conservation and landscape planning at different spatial scales, ranging from local case studies to trans-national analyses. For instance, the spatial extension and distribution of ecosystems are key indicators for the status of biodiversity, species extinction risks (IUCN 2010) and, by definition, of ecosystem status (Keith et al. 2013). Further, the quantitative and qualitative potential in provision of most ecosystem services is intimately linked to the composition and spatial configuration of the underlying habitat classes within the landscape of interest (Burkhard et al. 2012; Helfenstein \& Kienast 2014). The distribution of habitats may form the basis for relating structural and functional landscape heterogeneity to analyse biodiversity patterns in landscapes (Fahrig et al. 2011; Schindler et al. 2013) and may be useful to identify high nature value farmlands (Paracchini et al. 2008). The explanatory power of species distribution models can also be improved by using more accurate spatial information on ecosystems (Thuiller et al. 2004). Data on habitat distribution may also serve as a basis for quantifying the impact of invasive biota (Chytry et al. 2012). Finally, ecological network analysis, especially on broader scales, and associated conservation and planning actions (Groves et al. 2002; Watts et al. 2010) also need high-resolution ecosystem distribution data, e.g. to measure degrees of habitat fragmentation (Ostapowicz et al. 2006). In conclusion, we think that the $\mathrm{CEH}$ map represents a valuable tool for advancing both ecological research and spatial management planning in Central Europe.

\section{Data status and accessibility}

\section{Latest update}

15.02.2015

\section{Proprietary restrictions}

This dataset is freely available for non-commercial scientific use. 
Table 6 - Proportional shares (\%) of habitat classes in conservation areas and their surroundings (columns marked with asterisks) within the CEH mapping region. National parks and biosphere reserves are given in the upper and lower section, respectively. Highlighted fields either indicate greater (green) or reduced (red) shares of the corresponding habitat classes within protected areas.

\begin{tabular}{|c|c|c|c|c|c|c|c|c|c|c|c|c|c|c|c|c|c|c|c|c|c|c|}
\hline \multirow{3}{*}{$\begin{array}{l}\text { CEH } \\
\text { class }\end{array}$} & \multicolumn{22}{|c|}{ National Parks } \\
\hline & \multicolumn{12}{|c|}{ Austria } & \multicolumn{6}{|c|}{ Germany } & \multicolumn{2}{|l|}{ Italy } & \multicolumn{2}{|c|}{$\begin{array}{l}\text { Switzer- } \\
\text { land }\end{array}$} \\
\hline & $\mathrm{DON}^{*}$ & DON & GES* & GES & \begin{tabular}{|l|} 
HOT $^{*}$ \\
\end{tabular} & HOT & $\mathrm{KAL}^{*}$ & KAL & NEU* & NEU & THA* & THA & \begin{tabular}{|l|l|} 
BRW $^{*}$ \\
\end{tabular} & BRW & $\mathrm{BER}^{*}$ & BER & $\mathrm{SCH}^{*}$ & $\mathrm{SCH}$ & STJ* & STJ & GRB* & GRB \\
\hline CFO & 0.3 & 1.4 & 67.5 & 49.6 & 35.2 & 8.4 & 44.0 & 46.2 & 0 & 0 & 6.4 & 1.1 & 55.9 & \begin{tabular}{|l|l|}
58.4 & \\
\end{tabular} & 44.4 & 39.4 & 76.2 & 79.5 & 20.6 & 25.3 & 34.9 & 25.8 \\
\hline BLFO & 11.5 & 72.3 & 11.4 & 9.5 & 1.5 & 0.2 & 33.7 & 34.4 & 1.1 & 0.4 & 58.6 & 91.7 & 4.0 & 24.9 & 5.6 & 1.7 & 1.0 & 0.7 & 0.9 & 0.4 & 0.0 & 0.0 \\
\hline SHRUB & 0 & 0 & 4.3 & 14.7 & 12.1 & 16.7 & 0.5 & 11.1 & 0 & 0 & 0 & 0 & 0.1 & 14.8 & 11.0 & 11.2 & 6.1 & 13.0 & 6.0 & 9.0 & 1.5 & 1.7 \\
\hline ARAB & 65.3 & 4.4 & 0.0 & 0.0 & 0.4 & 0.0 & 0.0 & 0.0 & 43.9 & 1.7 & 32.1 & 0.4 & 0.5 & 0.0 & 0.1 & 0.0 & 1.6 & 0.0 & 2.7 & 1.0 & 0 & 0 \\
\hline IGR & 1.0 & 1.8 & 2.0 & 0.1 & 4.0 & 0.1 & 10.1 & 0.0 & 2.8 & 3.1 & 0.3 & 0.0 & 28.1 & 0.3 & 5.2 & 0.1 & 1.6 & 0.1 & 6.1 & 2.0 & 5.4 & 0.0 \\
\hline VIN & 0.2 & 0.0 & 0 & 0 & 0 & 0 & 0 & 0 & 21.2 & 1.7 & 0 & 0 & 0 & 0 & 0 & 0 & 0.1 & 0.0 & 0.1 & 0.0 & 0 & 0 \\
\hline ORC & 0 & 0 & 0 & 0 & 0 & 0 & 0 & 0 & 0.0 & 0.0 & 0 & 0 & 0 & 0 & 0 & 0 & 0 & 0 & 6.2 & 0.2 & 0 & 0 \\
\hline LAKE & 0.7 & 1.1 & 0.2 & 0.1 & 0.3 & 0.0 & 0.1 & 0.0 & 19.4 & 30.1 & 0 & 0 & 0.2 & 0.0 & 0.1 & 2.8 & 0.1 & 0.0 & 0.2 & 0.3 & 0.0 & 0.1 \\
\hline RIV & 0.8 & 6.9 & 0.4 & 0.4 & 0.3 & 0.0 & 0.5 & 0.5 & 0 & 0 & 0.0 & 1.9 & 0.2 & 0.0 & 0.4 & 0.1 & 0.6 & 0.1 & 0.3 & 0.2 & 0.6 & 0.2 \\
\hline RAIL & 1.4 & 0.2 & 0.5 & 0.2 & 0.1 & 0.0 & 0.2 & 0.0 & 0.1 & 0.0 & 0 & 0 & 0.4 & 0.1 & 0.1 & 0.0 & 0.2 & 0.0 & 0.1 & 0.0 & 0 & 0 \\
\hline ROAD & 1.8 & 0.1 & 0.4 & 0.2 & 0.2 & 0.0 & 0.5 & 0.0 & 0.1 & 0.0 & 0.1 & 0.0 & 0.3 & 0.0 & 0.6 & 0.0 & 0.5 & 0.4 & 0.2 & 0.1 & 0.5 & 0.2 \\
\hline BUA & 14.4 & 0.3 & 0.8 & 0.0 & 1.6 & 0.0 & 1.5 & 0.0 & 4.6 & 0.1 & 2.1 & 0.4 & 6.4 & 0.1 & 2.2 & 0.0 & 3.0 & 0.0 & 1.5 & 0.2 & 0.5 & 0.0 \\
\hline EXTGR & 0.9 & 3.1 & 8.7 & 4.4 & 21.2 & 10.9 & 7.3 & 7.5 & 2.2 & 9.7 & 0.2 & 1.4 & 2.1 & 0.5 & 8.0 & 8.3 & 6.5 & 0.2 & 20.3 & \begin{tabular}{|l|} 
\\
\end{tabular} & 12.9 & \begin{tabular}{|l|}
14.2 \\
\end{tabular} \\
\hline ALPGR & 0 & 0 & 0.4 & 0.5 & 14.8 & 21.3 & 0.0 & 0.1 & 0 & 0 & 0 & 0 & 0 & 0 & 1.6 & 6.3 & 0.0 & 0.0 & 17.2 & 14.3 & 23.2 & 21.7 \\
\hline WET & 0.1 & 1.2 & 0.2 & 0.0 & 0.4 & 0.3 & 0.2 & 0.0 & 2.8 & 43.6 & 0 & 0 & 1.7 & 0.7 & 0.7 & 0.2 & 1.4 & 4.5 & 0.1 & 0.1 & 0.0 & 0.0 \\
\hline DRY & 1.7 & 7.2 & 0.0 & 0.0 & 0.2 & 0.0 & 1.4 & 0.0 & 1.7 & 9.7 & 0 & 3 & 0.2 & 0.1 & 0.5 & 0.7 & 1.2 & 1.4 & 4.0 & 0.2 & 1.5 & 0.0 \\
\hline GRAVEL & 0 & 0 & 0.0 & 0.2 & 0.1 & 0.0 & 0.1 & 0.1 & 0 & 0 & 0 & 0 & 0 & 0 & 0.0 & 0.5 & 0 & 0 & 0.0 & 0.1 & 0.0 & 0.0 \\
\hline ROCK & 0 & 0 & 3.1 & 20.1 & 7.3 & 34.3 & 0 & 0 & 0 & 0 & 0 & 0 & 0 & 0 & 19.6 & 28.7 & 0 & 0 & 11.6 & 23.2 & 18.7 & 36.0 \\
\hline GLAC & 0 & 0 & 0 & 0 & 0.4 & 7.7 & 0 & 0 & 0 & 0 & 0 & 0 & 0 & 0 & 0 & 0 & 0 & 0 & 1.9 & 6.9 & 0.2 & 0.0 \\
\hline
\end{tabular}

\begin{tabular}{|c|c|c|c|c|c|c|c|c|c|c|c|c|c|c|c|c|c|c|c|c|}
\hline \multirow{3}{*}{$\begin{array}{l}\text { CEH } \\
\text { class }\end{array}$} & \multicolumn{20}{|c|}{ Biosphere reserves } \\
\hline & \multicolumn{10}{|c|}{ Austria } & \multicolumn{6}{|c|}{ Germany } & \multicolumn{4}{|c|}{ Switzerland } \\
\hline & NEU* $^{*}$ & NEU & $\mathrm{NOC}^{*}$ & NOC & \begin{tabular}{|l|} 
ULB $^{*}$ \\
\end{tabular} & ULB & WAL* & WAL & WIW* & WIW & $\mathrm{SCA}^{*}$ & SCA & \begin{tabular}{|c|}
$B G L^{*}$ \\
\end{tabular} & BGL & \begin{tabular}{|l|} 
RHÖ* \\
\end{tabular} & RHÖ & \begin{tabular}{|l|} 
ENT $^{*}$ \\
\end{tabular} & ENT & $\operatorname{VAM}^{*}$ & VAM \\
\hline CFO & 0.1 & 0.0 & 53.0 & 49.5 & 0.0 & 0.2 & 28.4 & 25.4 & 11.1 & 3.9 & 12.4 & 4.2 & 33.0 & 43.8 & 17.1 & 25.5 & 49.3 & 48.2 & 24.2 & 23.4 \\
\hline BLFO & 12.4 & 0.0 & 0.9 & 1.3 & 36.1 & 65.5 & 3.6 & 5.4 & 24.3 & 60.3 & 24.9 & 36.4 & 9.8 & 8.6 & 24.2 & 25.2 & 5.4 & 3.2 & 0.1 & 0.0 \\
\hline SHRUB & 0.1 & 0.0 & 9.5 & 9.2 & 0 & 0 & 9.9 & 12.0 & 0 & 0 & 0.1 & 0.0 & 5.3 & 5.0 & 0.1 & 0.3 & 1.0 & 0.1 & 2.2 & 1.4 \\
\hline ARAB & 18.4 & 0.1 & 1.1 & 0.1 & 31.8 & 3.8 & 0.7 & 0.0 & 31.6 & 7.7 & \begin{tabular}{|c|}
31.8 \\
\end{tabular} & $\mid 19.8$ & 1.3 & 2.0 & 38.3 & 16.3 & 0.8 & 0.4 & 0.9 & 0.0 \\
\hline IGR & 2.7 & 0.1 & 3.9 & 2.2 & 1.9 & 0.3 & 3.1 & 3.8 & 3.9 & 3.9 & \begin{tabular}{|l|}
13.7 \\
\end{tabular} & 15.3 & 21.1 & 17.1 & 8.0 & 11.7 & 14.6 & 30.4 & 5.9 & 3.0 \\
\hline VIN & 40.5 & 0 & 0 & 0 & 0 & 0 & 0 & 0 & 2.0 & 2.0 & 0 & 0 & 0 & 0 & 0 & 0 & 0 & 0 & 0 & 0 \\
\hline ORC & 0 & 0 & 0 & 0 & 0 & 0 & 0 & 0 & 0 & 0 & 0 & 0 & 0 & 0 & 0 & 0 & 0 & 0 & 0.1 & 0.0 \\
\hline LAKE & 3.5 & 55.2 & 1.6 & 0.2 & 2.5 & \begin{tabular}{|l|}
5.1 \\
\end{tabular} & 0 & 0 & 0.3 & \begin{tabular}{l|l} 
\\
\end{tabular} & 0.1 & 0.0 & 1.2 & 0.9 & 0 & 0 & 0.7 & 0.0 & 0.6 & 0.1 \\
\hline RIV & 0 & 0 & 0.3 & 0.2 & 4.7 & 0.0 & 0.4 & 0.7 & 1.2 & 0.3 & 0.2 & 0.1 & 0.5 & 0.7 & 0.4 & 0.2 & 0.4 & 0.5 & 0.3 & 0.2 \\
\hline RAIL & 0.2 & 0 & 0 & 0 & 0.1 & 0.0 & 0.1 & 0.0 & 1.1 & \begin{tabular}{l|l}
0.3 \\
\end{tabular} & 0.3 & 0.2 & 0.4 & 0.3 & 0.2 & 0.1 & 0 & 0 & 0 & 0 \\
\hline ROAD & 0.2 & 0 & \begin{tabular}{l|l|}
0.4 \\
\end{tabular} & 0.4 & 0.2 & 0.0 & 0.5 & 0.3 & 1.3 & 0.8 & 0.5 & 0.3 & 0.8 & 0.7 & 0.6 & 0.4 & 0.2 & 0.2 & 0.3 & 0.3 \\
\hline BUA & 6.0 & 0.1 & 2.5 & 1.5 & 7.7 & 0.0 & 3.4 & 0.8 & 18.1 & 11.6 & 8.9 & 6.1 & $\begin{array}{l}8.0 \\
\end{array}$ & 4.7 & 7.4 & 4.8 & 1.4 & 1.6 & 0.8 & 0.3 \\
\hline EXTGR & 5.4 & 0.1 & 18.0 & 22.9 & 4.0 & 1.4 & 34.2 & 39.6 & $\begin{array}{l}3.3 \\
\end{array}$ & 6.1 & 5.1 & \begin{tabular}{|l|}
13.4 \\
\end{tabular} & 7.2 & 5.5 & 2.3 & 12.7 & 18.0 & 6.9 & 13.7 & 16.9 \\
\hline ALPGR & 0 & 0 & 8.4 & 12.1 & 0 & 0 & 10.7 & 8.4 & 0 & 0 & 0 & 0 & 0.6 & 1.6 & 0 & 0 & 1.3 & 0.5 & 28.7 & 26.3 \\
\hline WET & 4.5 & 44.4 & 0.2 & 0.5 & 0.1 & 0.0 & 3.2 & 1.2 & \begin{tabular}{ll|}
0.0 \\
\end{tabular} & 0.1 & 0.4 & 0.2 & 1.4 & 1.0 & 0.4 & 1.7 & 5.3 & 5.9 & 0.2 & 0.1 \\
\hline DRY & 6.1 & 0 & 0 & 0 & 10.8 & 23.7 & 0.4 & 0.2 & 1.9 & \begin{tabular}{l|l}
2.9 \\
\end{tabular} & 1.6 & 3.8 & 0.2 & 0.6 & 0.9 & 1.0 & 0.3 & 0.3 & 1.6 & 0.4 \\
\hline GRAVEL & 0 & 0 & 0 & 0 & 0 & 0 & 0.2 & 0.1 & 0 & 0 & 0 & 0 & 0.0 & 0.1 & 0 & 0 & 0.2 & 0.1 & 0.1 & 0.0 \\
\hline ROCK & 0 & 0 & 0 & 0 & 0 & 0 & 1.2 & 2.1 & 0 & $\begin{array}{ll}0 \\
\end{array}$ & 0 & 0 & 9.1 & 7.3 & 0 & 0 & 0.9 & 1.3 & 18.3 & 27.7 \\
\hline GLAC & 0 & 0 & 0 & 0 & 0 & 0 & 0 & 0 & 0 & 0 & 0 & 0 & 0 & 0 & 0 & 0 & 0 & 0 & 1.8 & 0.0 \\
\hline
\end{tabular}

\section{Citation}

Data users must cite this Data Paper properly in any publication that results from an analysis using the provided data as a whole or in parts as: Kuttner, M., F. Essl, J. Peterseil, S. Dullinger, W. Rabitsch, S. Schindler, K. Hülber, A. Gattringer \& D. Moser 2015. A new high-resolution habitat distribution map for Austria, Liechtenstein, southern Germany, South Tyrol and Switzerland. eco.mont 7(2): 18-29.

\section{Collaboration}

Data users might consider collaboration and/or coauthorship with the data owners.

\section{Storage location \\ ftp://131.130.33.15}

\section{Acknowledgements}

We acknowledge funding by the Austrian Federal Ministry of Agriculture, Forestry, Environ- 
ment and Water Management (reference BMLFUWUW.1.3.3/0013-V/4/2013) and by the Austrian Climate and Energy Fund carried out within the framework of the "ACRP" Program (Project Number KR11AC0K00355, SpecAdapt; Project Number KR12AC5K01308; CCN-Adapt).

\section{References}

Bauerhansl, C., T. Koukal \& K. Schadauer 2008. Erste österreichweite Waldkarte basierend auf der Österreichischen Waldinventur. Available at: http:// www.waldwissen.net/themen/inventur_monitoring/ fernerkundung/bfw_waldlayer_2008_DE/

Berthoud, G., R.P. Lebeau \& A. Righetti 2004. Nationales ökologisches Netzwerk REN. Schlussbericht. Schriftenreihe Umwelt Nr. 373. Bundesamt für Umwelt, Wald und Landschaft. Bern.

Bundesamt für Statistik 2014. Dokumentation Waldmischungsgrad. Bundesamt für Statistik, Neuchâtel. Available at: http://www.bfs.admin.ch/ bfs/portal/de/index/dienstleistungen/geostat/ datenbeschreibung/waldmischungsgrad.parsys.0003. downloadList.00031.DownloadFile.tmp/dh404.pdf/

Burkhard, B., F. Kroll, S. Nedkov, F. Müller 2012. Mapping ecosystem service supply, demand and budgets. Ecological Indicators 21: 17-29.

Chytrý, M., J. Wild, P. Pyšek, V. Jarošík, N. Dendoncker, I. Reginster, J. Pino, L.C. Maskell, M. Vilà, I. Kühn, J.H. Spangenberg, J. Settele 2012. Projecting trends in plant invasions in Europe under different scenarios of future land use change. Global Ecology and Biogeography 21: 75-87.

Cremene, C., G. Gheorghe, L. Rakosy, A.A. Schileyko, A. Baur., A. Erhardt \&< B. Baur 2005. Alterations of Steppe-Like Grasslands in Eastern Europe: a Threat to Regional Biodiversity Hotspots. Conservation Biology 19 (5): 1606-1618.

Dirnböck, T. \& J. Peterseil 2014. Zwischenbericht zur CL Bewertung in Natura 2000 Gebieten Österreichs. In: Dirnböck, T. (ed.), Endbericht zur Eigentümerweisung „Critical Loads für Schwefel- und Stickstoffeinträge in Ökosysteme - Datenanfrage 2013/14": 4-14. Project report, Umweltbundesamt, Wien.

EEA 2007. CLC2006 technical guidelines. Technical report No 17/2007 - ISSN 1725-2237. Kopenhagen. DOI: $10.2800 / 12134$.

EEA 2013. EU-DEM. Available at: http://www. eea.europa.eu/data-and-maps/data/eu-dem (accessed $04 / 11 / 14)$

ESRI 2011. ArcGIS Desktop: Release 10. Redlands, CA: Environmental Systems Research 1999-2011.

European Commission 2006. Assessment, monitoring and reporting under Article 17 of the habitats Directive: explanatory notes \& guidelines. Final draft 5, October 2006. European Commission, Brussels.

Fahrig, L., J. Baudry, L. Brotons, F.G. Burel, T.O. Crist, R.J. Fuller, C. Sirami, G.M. Siriwardena \& J.L. Martin 2011. Functional landscape heterogeneity and animal biodiversity in agricultural landscapes. Ecology Letters 14/2: 102-112.

Falcucci, A., L. Maiorano \& L. Boitani 2007. Changes in land-use/land-cover patterns in Italy and their implications for biodiversity conservation. Landscape Ecology 22: 617-631.

Groves, C.R., D.B. Jensen, L.L. Valutis, K.H. Redford, M.L. Shaffer, M. Scott, J.V. Baumgartner, J.V. Higgins, M.W. Beck \& M.G. Anderson 2002. Planning for Biodiversity Conservation: Putting Conservation Science into Practice. BioScience 52 (6): 499-512.

Helfenstein, J. \& F. Kienast 2014. Ecosystem service state and trends at the regional to national level: A rapid assessment. Ecological Indicators 36: 11-18.

Hijmans, R.J., S.E. Cameron, J.L. Parra, P.G. Jones \& A. Jarvis 2005. Very high resolution interpolated climate surfaces for global land areas. International Journal of Climatology 25: 1965-1978.

Hooftman, D.A.P. \& J.M. Bullock 2012. Mapping to inform conservation: A case study of changes in seminatural habitats and their connectivity over 70 years. Biological Conservation 145: 30-38.

Holzner, W. (ed.) 1986. Österreichischer Trockenrasenkatalog. Grüne Reihe des Bundesministeriums für Gesundheit und Umweltschutz Band 6. Styria Medienservice, Graz.

IUCN 2010. Guidelines for using the IUCN Red List categories and criteria. Version 8.1. Available at: http://intranet.iucn.org/webfiles/doc/SSC/RedList/ RedListGuidelines.pdf/

Keith, D., J.P. Rodríguez, K.M. Rodríguez-Clark, E. Nicholson, K. Aapala, A. Alonso, M. Asmussen, S. Bachman, A. Basset, E. g. Barrow, J.S. Benson, M.J Bishop, R. Bonifacio, T.M. Brooks, M.A. Burgman, P. Comer, F.A. Comín, F. Essl, D. Faber-Langendoen, P.G. Fairweather, R.J. Holdaway, M. Jennings, R.T. Kingsford, R.E. Lester, R. Mac Nally, M.A. McCarthy, J. Moat, M.A. Oliveira-Miranda, P. Pisanu, B. Poulin, T.J. Regan, U. Riecken, M.D. Spalding \& S. ZambranoMartínez 2013. Scientific foundations for an IUCN Red List of Ecosystems. PLoS One 8(5): e62111.

Kempeneers, P., F. Sedano, L. Seebach, P. Strobl \& J. San-Miguel-Ayanz 2011. Data Fusion of Different Spatial Resolution Remote Sensing Images Applied to Forest-Type Mapping. IEEE Transactions on Geoscience and Remote Sensing 49 (12): 4977-4986.

Klötzli, F. \& Ab.P. Grootjans 2001. Restoration of Natural and Semi-Natural Wetland Systems in Central Europe: Progress and Predictability of Developments. Restoration Ecology 9 (2): 209-219.

Körner, C. 2012. Alpine Treelines - Functional Ecology of the Global High Elevation Tree Limits. Springer Basel. DOI: 10.107/978-3-0348-0396-0

Kundel, H.L. \& M. Polansky 2003. Measurement of Observer Agreement. Radiology 228: 303-308.

Landis, J.R. \& G.G. Koch 1977. The measurement of observer agreement for categorical data. Biometrics 33: 159-174. 
Langanke, T. 2013. GIO land (GMES/Copernicus initial operations land) High Resolution Layers (HRLs) - summary of product specifications; Version 6 of 2013-07-08. European Environmental Agency, Copenhagen. Available at: http://land.copernicus.eu/ user-corner/publications/gio-land-high-resolutionlayers/view/

LfU 2012. Biotopkartierung Bayern - Stand 2012. Bayerisches Landesamt für Umwelt. Available at: http://www.lfu.bayern.de/natur/doc/liesmich_ bk.pdf

LUBW 2014. Kartieranleitung FFH-Lebensraumtypen und Biotoptypen Baden-Württemberg. Landesanstalt für Umwelt, Messungen und Naturschutz Baden Württemberg. Available at: http:// www.lubw.baden-wuerttemberg.de/servlet/ is $/ 11168 /$ ?shop=true/

Ostapowicz, K., C. Estreguil, J. Kozak \& P. Vogt 2006. Assessing forest fragmentation and connectivity: a case study in the Carpathians. SPIE Digital Library, The Remote Sensing for Environmental Monitoring, GIS Applications and Geology VI Conference Proceedings Vol. 6366/ 636608 ss. 10.

Paracchini, M.L., J.-E. Petersen, Y. Hoogeveen, C. Bamps, I. Burfield \& C. van Swaay 2008. High Nature Value Farmland in Europe - An Estimate of the Distribution Patterns on the Basis of Land Cover and Biodiversity Data. EUR - Scientific and Technical Research series. Luxembourg. DOI: 10.2788/8891.

Schindler, S., H. von Wehrden, K. Poirazidis, T. Wrbka \& V. Kati 2013. Multiscale performance of landscape metrics as indicators of species richness of plants, insects and vertebrates. Ecological Indicators 31: 41-48.

Schmit, C., M.D.A. Rounsevell \& I. La Jeunesse 2006. The limitations of spatial land use data in environmental analysis. Environmental Science \& Policy 9: 174-188.

Steiner, G.M. 1992. Österreichischer Moorschutzkatalog. Graz.

Thuiller, W., M.B. Araújo \& S. Lavorel 2004. Do we need land-cover data to model species distributions in Europe? Journal of Biogeography 31: 353-361.

Watts, K., A.E. Eycott, P. Handley, D. Ray, J.W. Humphrey \& C.P. Quine 2010. Targeting and evaluating biodiversity conservation action within fragmented landscapes: an approach based on generic focal species and least-cost networks. Landscape Ecology 25: 1305-1318.

\section{Authors}

\section{Michael Kuttner'}

has been working in the fields of landscape and vegetation ecology. His research focuses on the relation between biodiversity and landscape structure, GIS and species distribution modelling. Corresponding author. Email: michael.kuttner@univie.ac.at

\section{Franz Ess| ${ }^{1,2}$}

is mainly interested in the causes and impacts of biological invasions, the effects of global change on the distribution of species, and in understanding the processes and patterns of biodiversity. In addition, he is involved in biodiversity conservation and implementing conservation policies.

\section{Johannes Peterseil ${ }^{2}$}

is interested in biodiversity and landscape ecology. His research is ranging from landscape ecology, biodiversity monitoring, ecosystem services and environmental data management.

\section{Stefan Dullinger ${ }^{1}$}

is mainly interested in the effects of global change on the distribution of species and on spatio-temporal biodiversity patterns, with a special focus on mountain plant diversity. He also works on biological invasions and issues of conservation biogeography.

\section{Wolfgang Rabitsch²}

works at the science-policy-interface with a focus on nature conservation, biological invasions, risk assessments, climate change, biodiversity indicators, and conservation biogeography. He is fond of insects.

\section{Stefan Schindler ${ }^{2}$}

is interested in biodiversity and nature conservation. His research covers a diverse set of disciplines such as landscape ecology, agro-, grassland and forest ecology and management, ecosystem services and invasion biology. His taxonomic expertise is focused on birds.

\section{Karl Hülber}

is interested in plant biogeography and various aspects of plant ecology with a special focus on evolutionary ecology of mountain plants.

\section{Andreas Gattringer}

is a computer scientist, mainly responsible for programming and maintenance of dynamic distribution models at the Department of Botany and Biodiversity Research of the University Vienna.

\section{Dietmar Moser ${ }^{1,2}$}

is an ecologist with his main interests in plant-animal interactions, in vegetation dynamics, in diversity patterns, in causes and pattern of biological invasions and in the impact of climate change on distribution of biota.

${ }^{1}$ Department of Conservation Biology, Vegetation and Landscape Ecology, University of Vienna, Rennweg 14, 1030 Vienna, Austria

${ }^{2}$ Environment Agency Austria, Spittelauer Lände 5, 1090 Vienna, Austria 